V.S. Moravskyi, V.Ye. Levytskyi, A.S. Masyuk, U.V. Khromiak

\title{
INFLUENCE OF MODIFIED COMPACTED EXPANDED POLYSTYRENE ON THE RHEOLOGICAL PROPERTIES OF POLYAMIDE 6 AND POLYSTYRENE
}

\author{
Lviv Polytechnic National University, Lviv, Ukraine
}

\begin{abstract}
The influence of the compacted expanded polystyrene modified by polyvinylpyrrolidone on the rheological properties of polyamide 6 and polystyrene are established in this work. The modified expanded polystyrene significantly affects the dependence of the viscosity of polyamide 6 melt on the shear stress, which is caused by physical interactions between the components of the system, primarily between the functional groups of polyamide 6 and polyvinylpyrrolidone. The effects of the temperature and the content of modified expanded polystyrene on the flow behavior index, the constant of the rheological equation and the activation energy of the viscous flow of polyamide 6 and polystyrene melts are revealed. The polyamide 6 flow behavior index in the Newtonian region is independent of the content of modified expanded polystyrene and temperature and is close to 1 . The influence of the modifier on the flow behavior index in the non-Newtonian region is more pronounced at low temperatures. With an increase in the content of modified expanded polystyrene, the effective viscosity of the polyamide 6 melt decreases, and the value of the shear rate of the beginning of development of the anomaly of viscosity increases. The value of the flow behavior index of the blends of polystyrene with modified expanded polystyrene increases with an increase in the content of modified expanded polystyrene and does not depend on the temperature. This is obviously due to an increase in the content of a component with lower molecular weight and, consequently, an increase in the overall polydispersity of the system.
\end{abstract}

Keywords: polyamide 6, expanded polystyrene, rheological properties, polymer blends, polyvinylpyrrolidone.

DOI: $10.32434 / 0321-4095-2019-122-1-35-41$

\section{Introduction}

The modern development of science and technology requires the creation of new materials with a complex of special properties. Among such materials, on the basis of which it is possible to obtain new composites with required operational properties, special attention is paid to polyamides, which have high strength and resistance to impact loads [1]. However, polyamides have a number of properties that to some extent restrict their use as constructional materials. First of all, these are increased water absorption, large technological shrinkage and low viscosity of melts. The improvement of the properties of polyamides by synthesizing new representatives of this kind of polymers is unlikely, since practically all possible variants of compounds with an amide group have already been synthesized and tested [2]. New composite materials can be obtained by combining thermoplastics [3] and thermoplastics with thermosetting plastics of different nature [4,5], in particular, polystyrene (PS) and polyamide 6 (PA-6) in the viscous state, including by using special equipment [6]. The disadvantages of polyamide 6 as a structural material can be eliminated by its combining in a viscous state with an amorphous hydrophobic polystyrene that is modified by polyvinylpyrrolidone (PVP). The use of polyvinylpyrrolidone for creating composite materials based on blends of various thermoplastics of different nature is caused by a combination of a set of unique properties inherent to it, such as high activity to a surface of different nature, controlled water absorption, sorption capacity and the ability to formation of complexes [7,8]. However, if in the case of polyamide 6 it is possible to obtain homogeneous blends with polyvinylpyrrolidone due 
to the ability to dissolve in a polyamide 6 matrix when mixed in a viscous-flow state, then in the case of polystyrene, the combination with polyvinylpyrrolidone in the viscous state results in the formation of a heterogeneous structure. To obtain a modified polystyrene in which polyvinylpyrrolidone is uniformly distributed at the molecular level, a method has been developed which involves the treatment of expanded polystyrene (EPS) or its wastes in a continuous reactor with a heated butanol solution of polyvinylpyrrolidone. As a result of the sorption of polyvinylpyrrolidone with expanded polystyrene and its gradual condensation, the modified expanded polystyrene with a density close to the density of polystyrene was obtained, in the volume of which uniformly distributed $20 \mathrm{wt} \%$ of polyvinylpyrrolidone.

Polymeric composite materials are chiefly produced by injection molding [9]. Therefore, understanding the essence of the rheological properties of composite materials is very important to establish optimal processing conditions, choose the design of snap-in and power-strength parameters of the equipment, and predict the mechanical and physical properties of end products [10].

\section{Materials and methods}

Degassing EPS with simultaneous polyvinylpyrrolidone modification was carried out in butanol solution. To this end, the calculated amount of PVP was pre-dissolved in butanol and the prepared solution was loaded into a degasser reactor together with the shredded EPS waste. The process was performed at the temperature of $90^{\circ} \mathrm{C}$ under continuous stirring for 1.5 hours. After degassing, the modified EPS was unloaded from the reactor and dried in a vacuum dryer at $60^{\circ} \mathrm{C}$ to reach a constant mass. To fabricate polystyrene-polyamide 6 materials, the polyamide 6 (PA-6 120/321 OST-6-06-C9-83) and degassed modified polystyrene (domestic and industrial waste polystyrene (TU 6-05-1178-87) with a density of $\left.20-50 \mathrm{~kg} / \mathrm{m}^{3}\right)$ were used.

Polymer blends of modified EPS and thermoplastics were prepared using a Cellier laboratory extruder which was equipped with a screw (the length of $700 \mathrm{~mm}$ and the diameter of $25 \mathrm{~mm}$ ). The screw speed was $50 \mathrm{rpm}$. The temperature ranges of the extruder zones for the blends based on polyamide 6 were $483-488,498-503$, and $513-518 \mathrm{~K}$. The temperature ranges of the extruder zones for the blends based on polystyrene were 463-468, 478483 , and $498-503 \mathrm{~K}$. The final extrudate was crushed in a gear-type crusher. The production of standard samples of granular material was carried out by the injection molding method using a thermosetting machine Krauss Maffei KM 110-390 C2.

The flow curves of melting of polymer blends were recorded by a MFI apparatus «IIRT-M» using capillaries that had a length of 8 and $25 \mathrm{~mm}$ and a diameter of $2.095 \pm 0.005 \mathrm{~mm}$. The volume flow of material in the capillary was calculated by the following formula [11,12]:

$\mathrm{Q}=\frac{\mathrm{S} \pi \mathrm{d}^{2}}{4 \mathrm{t}}$,

where $\mathrm{S}$ is the displacement of the piston, $\mathrm{m}$; $\mathrm{d}$ is the diameter of the piston, $\mathrm{m}$; and $\mathrm{t}$ is the time of movement.

The effective rate of displacement in the capillary was determined using the expression:

$\gamma_{\mathrm{ef}}=\frac{4 \mathrm{Q}}{\pi \mathrm{r}^{3}}$,

where $r$ is the radius of capillary, $m$.

The tensile shear in the capillary was calculated by the following formula:

$\tau=\frac{\Delta \mathrm{P} \cdot \mathrm{r}}{2 \mathrm{~L}}=\frac{9,81 \cdot 4 \cdot \mathrm{r} \cdot \mathrm{P}}{\pi \mathrm{d}^{2} \cdot 2 \mathrm{~L}}$,

where $\mathrm{P}$ is the weight of cargo, $\mathrm{kg} ; \Delta \mathrm{P}$ is the pressure drop between the ends of the capillary; and $\mathrm{L}$ is the capillary length, $\mathrm{m}$.

The shear rate was determined by plotting an auxiliary curve of the strain stress vs. the shear rate in the logarithmic coordinates taking into account the correction of Rabinovich and the WeissenbergRabinovich method [12]. Differentiating the obtained dependence allows obtaining the index of viscosity anomaly from the slope of the curve. Hence, the shear rate can be determined as follows:

$\gamma=\frac{(3 n+1)}{4 n} \gamma_{\mathrm{ef}}$,

where $\mathrm{n}$ is the flow behavior index (characterizing the degree of non-Newtonian behavior).

The effective viscosity was calculated as the ratio of the displacement stress to the shear rate:

$\eta=\frac{\tau}{\gamma}$.

The following rheological equation was used to determine its constants: 


$$
\tau=\mathrm{m}_{0} \cdot \exp \left(\frac{\mathrm{E}}{\mathrm{RT}}\right) \cdot \gamma^{\mathrm{n}}
$$

where $\tau$ is the displacement stress of the polymer mixture, $\mathrm{Pa} ; \eta$ is the viscosity, $\mathrm{Pa} \cdot \mathrm{s} ; \gamma$ is the shear rate, $\mathrm{s}^{-1} ; \mathrm{n}$ is the flow behavior index; $\mathrm{E}$ is the imaginary activation energy of the viscous flow, $\mathrm{J} \mathrm{mol}^{-1}$; and $\mathrm{m}_{0}$ is a constant that depends on the nature of the material, Pa.s.

The activation energy of the viscous flow of melting of polymers and their blends was determined according to the following equation:

$\mathrm{E}_{\mathrm{a}}=2.303 \cdot \mathrm{R} \cdot \lg \frac{\left(\eta_{\mathrm{T} 2}-\eta_{\mathrm{T} 1}\right)}{\left(1 / \mathrm{T}_{2}-1 / \mathrm{T}_{1}\right)}$

where $\eta_{\mathrm{T} 1}$ and $\eta_{\mathrm{T} 2}$ are the viscosities of the material at the temperatures $T_{1}$ and $T_{2}$, respectively.

\section{Results and discussion}

The rheological properties of the materials under study were evaluated by capillary viscometry at various temperatures: at 503 and $513 \mathrm{~K}$ for the compositions based on PA- 6 with EPS modified by polyvinylpyrrolidone and at 473 and $503 \mathrm{~K}$ for the compositions based on PS with EPS modified by polyvinylpyrrolidone.

The dependence of the effective viscosity on the shear rate of melts of blends based on PA-6 with different contents of the modifying component is shown in Fig. 1.

As can be seen (Fig. 1,a), the dependence of the effective viscosity on the shear rate for PA-6 does not practically change up to the shear rate of $70 \mathrm{~s}^{-1}$; a further increse in the the shear rate causes a deacrese of the effective viscosity as a result of the development of the viscosity anomaly. The addition

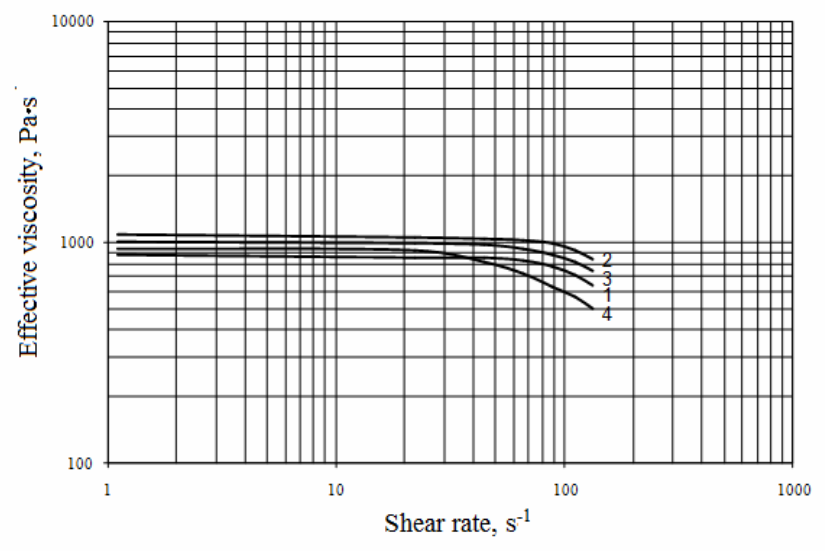

Fig. 1. Flow curves of blends PA-6 modified by EPS at $503 \mathrm{~K}$ (a) and $513 \mathrm{~K}$ (b). The content of the modified EPS, wt.\%:

Fig. 1. Flow curves of blends PA-6 modified by EPS at $503 \mathrm{~K}$ (a) and $513 \mathrm{~K}$ (b)
\[ (1)-0 ;(2)-1 ;(3)-5 ;(4)-10 \] of the modified EPS does not change the character of the rheological curves, however, the values of effective viscosity and shear rate, at which the viscosity anomaly occurs, change. This is especially pronounced for small amounts of the modifier. Thus, the value of the effective viscosity in the Newtonian region is the highest (1400 $\mathrm{Pa} \cdot \mathrm{s})$ and the viscosity anomaly begins even at the shear rate of $30 \mathrm{~s}^{-1}$ when the modifier content is $1 \%$.

A further increase in the content of the modified EPS in the mixture leads to a decrease in the effective viscosity to $1100 \mathrm{~Pa} \cdot \mathrm{s}$, and the value of the shear rate of the onset of the viscosity anomaly increases to $50 \mathrm{~s}^{-1}$. Attention should be paid to the nature of the dependencies in the non-Newtonian field in which the opposite dependence is observed. Indeed, a mixture of PA-6 with $1 \%$ modified EPS has the lowest effective viscosity and the pure PA-6 is characteristicted by the highest effective viscosity.

This feature of the dependence of the effective viscosity on the shear rate can be explained by the presence of polyvinylpyrrolidone in the modified EPS, which is evenly distributed at the molecular level and takes an active part in the redistribution of intermolecular bonds in the polycaproamide with the formation of hydrogen bonds between carbamate groups of PVP and peptide groups of polyamide 6 . The redistribution of the bond contributes to the creation of a denser fluctuation network and an increase in the viscosity.

At a small content of the modified EPS, an increase in the shear rate leads, first of all, to the destruction of hydrogen bonds between carbamate groups of PVP and peptide groups of polyamide 6 . This causes a decrease in the density of the fluctuation

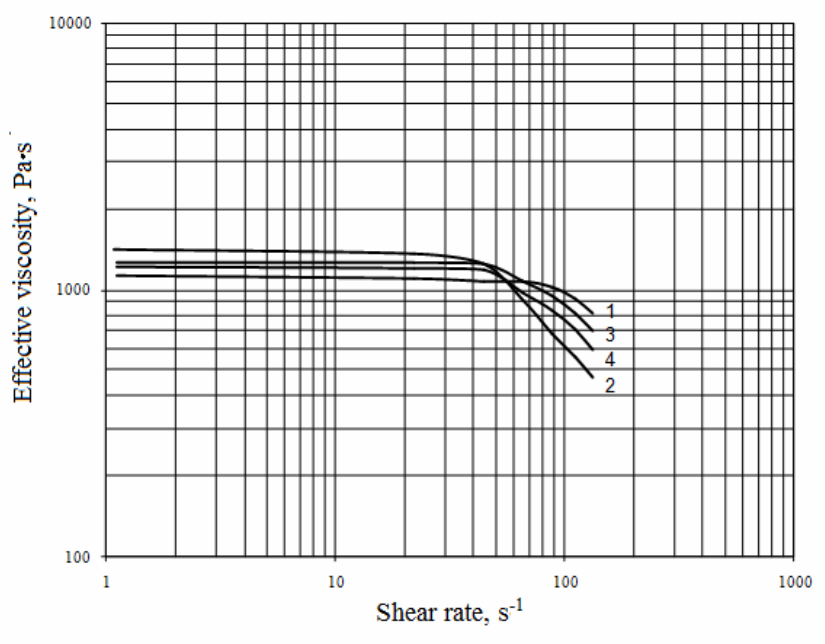


grid and to the development of an anomaly of viscosity at a lower shear rate. Some decrease in the viscosity of blends with increasing the amount of modified EPS can be explained by an increase in the amount of a component with a lower viscosity. Due to stronger connections between the functional groups of the components of the mixture, the viscosity anomaly begins at high shear rates. It should be noted that the hydrogen bonds between peptide PA-6 groups persist even in the molten state.

An increase in the temperature leads to a decrease in the effective viscosity of the blends and does not affect the nature of the flow curves in the Newtonian region (Fig. 1,b) [13]. A decrease in the value of effective viscosity of the melts of the mixture with an increase in the content of the modified EPS is due to the fact that the strength of the hydrogen bonds between the PA- 6 macromolecules deminishes more significantly at increased temperature than those between the PVP and PA-6 macromolecules and the presence of a large amount of the low-viscosity component.

The effect of the modified EPS on the character of the flow curves of a suspension PS is shown in Fig. 2.

The effect of the modified EPS on the rheological properties of polystyrene (Fig. 2) is manifested in a decrease of the viscosity of the blends with an increase in its amount without changing the nature of the curves due to the absence of groups that interact with PVP and an increase in the content of a component with lower viscosity.

With increasing the temperature, the viscosity of the melts of polystyrene-modified EPS blends naturally decreases. The dependences of the relative viscosity on the shear stress confirms the effect of

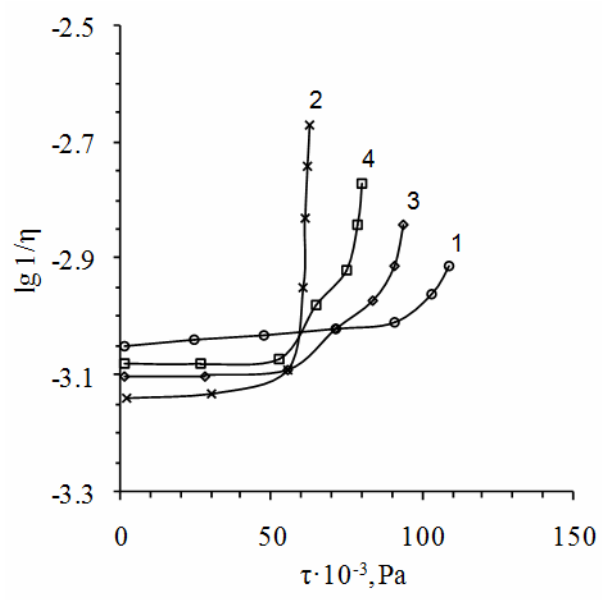

a

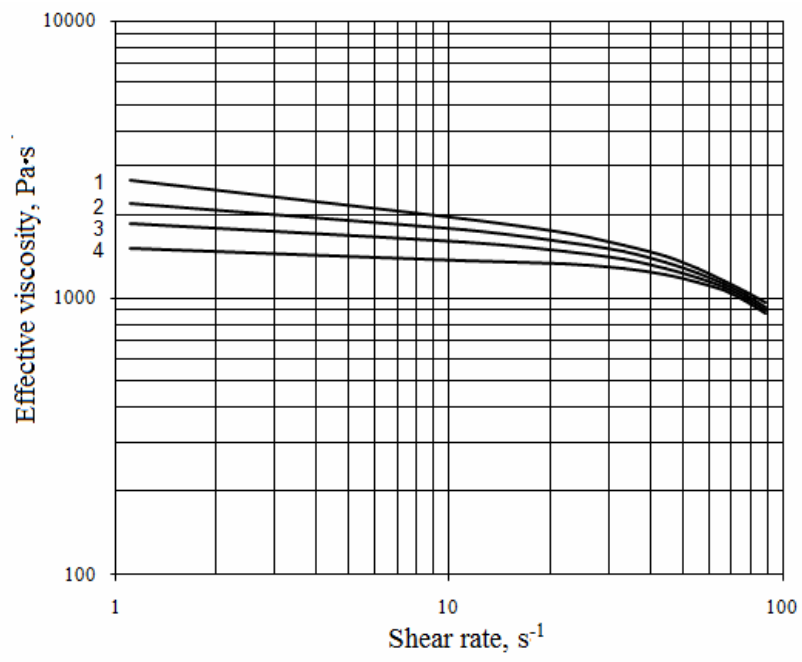

Fig. 2. Flow curves of blends PS modified by EPS at $473 \mathrm{~K}$. The content of the modified EPS, wt.\%: (1) -0 ; (2) -1 ;

$$
\text { (3) }-5 \text {; (4) }-10
$$

the modified EPS and temperature on the development of the viscosity anomaly of the blends PA-6 modified by EPS (Fig. 3) and PS modified by EPS (Fig. 4).

The modified EPS significantly affects the nature of the dependence of the viscosity on the shear stress in the case of blends based on PA-6 (Fig. 3). After reaching a certain critical stress $(50 \div 100 \mathrm{kPa})$, the nature of the curves changes which is caused by physical interactions between the components of the mixture. The lack of influence of the modifier on the nature of the dependencies for the blends based on PS (Fig. 4) confirms the absence of specific interactions in the system.

The effects of the content of the modified EPS and temperature on the effective viscosity at a

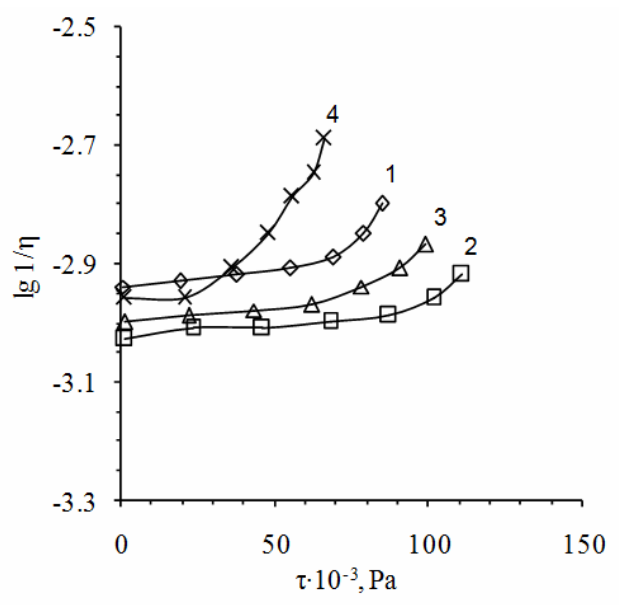

b

Fig. 3. Dependence of the melt viscosity of mixture PA-6 modified by EPS on the shear stress at $503 \mathrm{~K}$ (a) and $513 \mathrm{~K}$ (b). The content of the modified EPS, wt.\%: (1) - 0; (2) - 1; (3) - 5; (4) - 10 


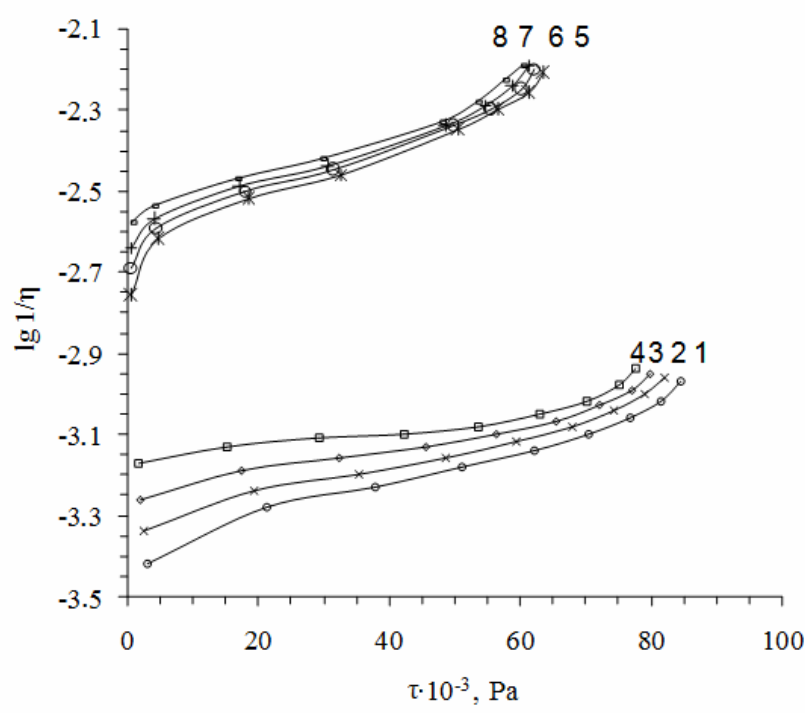

Fig. 4. Dependence of the melt viscosity of mixture of PS modified by EPS on the shear stress at different temperatures, $\mathrm{K}:(1)-(4) 473,(2)-(8) 503$. The content of modified EPS, wt.\%: (1), (5) - 0; (2), (6) - 1; (3), (7) - 5; (4), (8) - 10

constant shear stress for the blends under consideration in various flow regions are shown in Fig. 5.

In case of the blends based on PA-6, the content of the modified EPS and temperature affect the value of the effective viscosity in both Newtonian and non-Newtonian regions. This influence at $503 \mathrm{~K}$ is not the same for different fields. This confirms that the density of the fluctuation grid formed by hydrogen bonds between different functional groups depends significantly on both the temperature and the shear rate. In case of the PC-based blends, a monotonic decrease in viscosity in both Newtonian

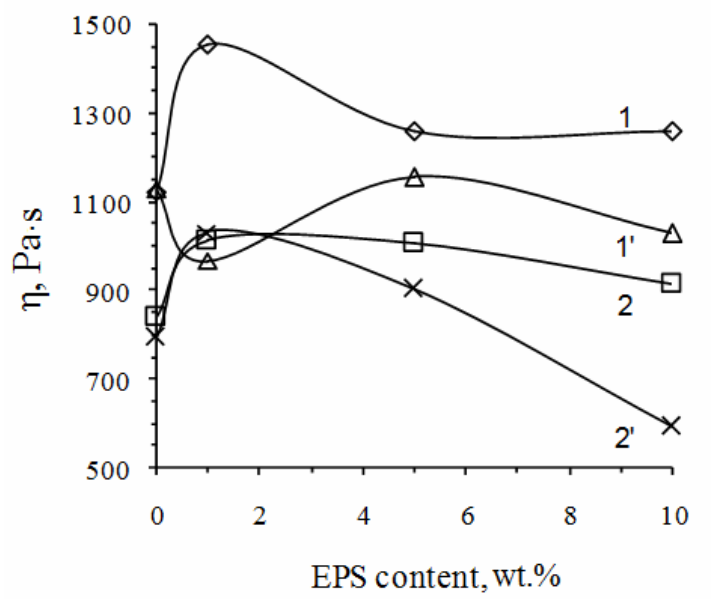

a

Fig. 5. Dependences of the effective viscosity of the blends PA-6 modified by EPS (a) and PS modified by EPS (b) on the EPS and non-Newtonian regions indicates the absence of specific interactions between the components of the mixture. Increasing the temperature leads to a decrease in the viscosity and the scope of the curve.

On the basis of rheological study, the constants $\mathrm{n}, \mathrm{m}_{0}$ in the equation (6) and the activation energy of the viscous flow, $E_{a}$, were calculated. Viscous flow is an activated process, the elementary act of which is the movement of a segment from one equilibrium position to another. The activation energy of the viscous flow, $E_{a}$, determines the energy that the segment should receive as a result of the fluctuations in thermal energy and which is necessary for detaching the segment from the segments surrounding it. The magnitude of the flow behavior index $n$ shows the intensity of the development viscosity anomaly of the studied blends and the constant $\mathrm{m}_{0}$ characterizes the intermolecular interactions between the components of the system [14].

Comparing the values of the rheological constants for the blends PA- 6 modified by EPS (Table 1), it should be noted that the flow behavior index $\mathrm{n}$ in the Newtonian region does not depend on the content of the modified EPS and also the temperature; it is close to 1 . At the same time, the effect of the modifier on the flow behavior index for the non-Newtonian region is more significant at a low temperature.

The highest manifestation of the viscosity anomaly is observed for the mixture with $1 \%$ modified EPS, which is caused by intermolecular interactions between polar groups of PVP and PA-6. An increase in temperature leads to a partial breakdown of these bonds; therefore, the deviation of the flow behavior index of the melts of blends becomes smaller than

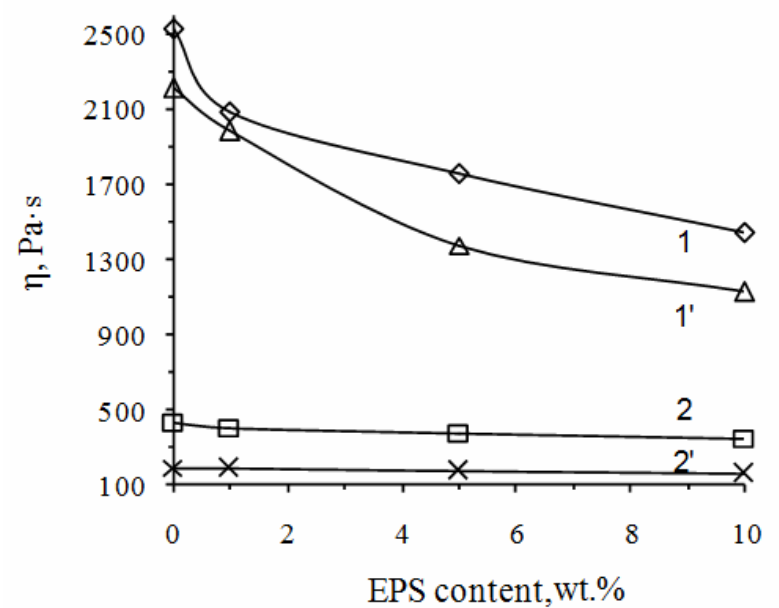

b content. (1) and (2) - the Newtonian flow region $\left(\mathrm{t}=4 \cdot 10^{3} \mathrm{~Pa}\right),\left(1^{\prime}\right)$ and $\left(2^{\prime}\right)-$ the non-Newtonian flow region $\left(\mathrm{t}=6 \cdot 10^{4} \mathrm{~Pa}\right)$ :
\[ \mathrm{a}-(1),\left(1^{\prime}\right)-\mathrm{T}=503 \mathrm{~K} ;(2),\left(2^{\prime}\right)-\mathrm{T}=513 \mathrm{~K} ; \mathrm{b}-(1),\left(1^{\prime}\right)-\mathrm{T}=473 \mathrm{~K} ;(2),\left(2^{\prime}\right)-\mathrm{T}=503 \mathrm{~K} \]
Influence of modified compacted expanded polystyrene on the rheological properties of polyamide 6 and
polystyrene content. (1) and (2) - the Newtonian flow region $\left(\mathrm{t}=4 \cdot 10^{3} \mathrm{~Pa}\right),\left(1^{\prime}\right)$ and $\left(2^{\prime}\right)-$ the non-Newtonian flow region $\left(\mathrm{t}=6 \cdot 10^{4} \mathrm{~Pa}\right)$ :
\[ \mathrm{a}-(1),\left(1^{\prime}\right)-\mathrm{T}=503 \mathrm{~K} ;(2),\left(2^{\prime}\right)-\mathrm{T}=513 \mathrm{~K} ; \mathrm{b}-(1),\left(1^{\prime}\right)-\mathrm{T}=473 \mathrm{~K} ;(2),\left(2^{\prime}\right)-\mathrm{T}=503 \mathrm{~K} \]
Influence of modified compacted expanded polystyrene on the rheological properties of polyamide 6 and
polystyrene 
Influence of temperature and content of modified EPS on the constants of the rheological equation for PA-6

\begin{tabular}{|c|c|c|c|c|c|c|c|}
\hline \multirow{2}{*}{ No. } & \multirow{2}{*}{$\begin{array}{l}\text { Content of } \\
\text { EPS wt. } \%\end{array}$} & \multicolumn{4}{|c|}{$\mathrm{n}$} & \multirow{2}{*}{$\mathrm{m}_{\mathrm{o}} \cdot 10^{10}, \mathrm{MPa} \cdot \mathrm{s}^{\mathrm{n}}$} & \multirow{2}{*}{$\mathrm{E}_{\mathrm{a}}, \mathrm{kJ} \mathrm{mol}^{-}$} \\
\hline & & \multicolumn{2}{|c|}{$503 \mathrm{~K}$} & \multicolumn{2}{|c|}{$513 \mathrm{~K}$} & & \\
\hline 1 & 0 & \multirow{4}{*}{$1.00 *$} & $0.59 * *$ & \multirow{4}{*}{1.00} & 0.62 & 27.1 & 54.1 \\
\hline 2 & 1 & & 0.08 & & 0.70 & 19.6 & 56.4 \\
\hline 3 & 5 & & 0.35 & & 0.68 & 47.2 & 52.3 \\
\hline 4 & 10 & & 0.23 & & 0.52 & 10.8 & 58.3 \\
\hline
\end{tabular}

Note: $*$ - Newtonian flow region $\left(\gamma=20 \mathrm{~s}^{-1}\right) ; * *$ non-Newtonian flow region $\left(\gamma=100 \mathrm{~s}^{-1}\right)$.

that of pure polyamide 6 . This also affects the value of the activation energy of the viscous flow, which in this case weakly depends on the content of the modified EPS.

The value of the flow behavior index of the PS blends modified by EPS increases with an increase in the content of the modified EPS and does not depend on the temperature (Table 2). This is caused by an increase in the content of a component with lower molecular weight, and as a result, an increase in the overall polydispersity of the blend. The activation energy of viscous flow decreases with an increase in the content of the modifier which can be explained both by an increase of the content of PS with low molecular weight and by the presence of polyvinylpyrrolidone in the modified EPS, which, due to low compatibility with PS, increases the heterogeneity of the system. This leads to an increase in the free volume of the polymer and a decrease in the activation energy of the viscous flow. Significantly low values of the constant $\mathrm{m}_{0}$ in comparison with the blends of PA-modified EPS confirm the absence of interactions between the components of the mixture PS-modified EPS.

Table 2

Influence of the temperature and the content of modified EPS on the constants of the rheological equation for blends PS-EPS in the Newtonian flow region*

\begin{tabular}{c|c|c|c|c|c}
\hline \multirow{2}{*}{ No } & Content of & \multicolumn{2}{|c|}{$\mathrm{n}$} & $\mathrm{m}_{\mathrm{o}} \cdot 10^{14}$, & $\mathrm{E}_{\mathrm{a}}, \mathrm{kJ} \mathrm{mol}^{-1}$ \\
\cline { 3 - 4 } & EPS wt.\% & $473 \mathrm{~K}$ & $503 \mathrm{~K}$ & $\mathrm{MPa} \cdot \mathrm{s}^{\mathrm{n}}$ & \\
\hline 1 & 0 & 0.85 & 0.85 & 2.38 & 100.1 \\
\hline 2 & 1 & 0.90 & 0.90 & 3.60 & 97.7 \\
\hline 3 & 5 & 0.93 & 0.93 & 6.77 & 94.5 \\
\hline 4 & 10 & 0.95 & 0.95 & 17.33 & 90.0 \\
\hline
\end{tabular}

Note: $*-\gamma \leq 10 \mathrm{~s}^{-1}$.

\section{Conclusions}

Thus, our findings indicate a significant effect of the modified EPS on the rheological properties of polyamide 6 and polystyrene, which, first of all, can be explained by intermolecular interactions between the components of the mixture. The industrial tests confirmed the adaptability and efficiency of the materials based on thermoplastic modified by EPS to manufacture electrical and structural products with enhanced performance, high dimensional stability and reduced water absorption.

\section{REFERENCES}

1. Mai Y.-W., Yu Z.-Z. Polymer nanocomposites. Cambridge: Woodhead Publishing Limited, 2006. - 608 p.

2. Polyesters and polyamides / Deopura B.L., Alagirusamy R., Joshi M., Gupta B. - Cambridge: Woodhead Publishing Limited, 2008. $-632 \mathrm{p}$.

3. The influence of polystyrene modifier and plasticizer nature on the properties of poly(vinyl chloride) / Levytskyj V., Laruk Y., Humenetsky T., Sikora J. // Chemistry and Chemical Technology. - 2015. - Vol.9. - No. 2. - P.199-203.

4. Physicochemical properties of modified polyesterpolyvinylchloride compositions / Levyts'kyi V.E., Katruk D.S., Shybanova A.M., Bilyi L.M., Humenets'kyi T.V. // Materials Science. - 2017. - Vol.52. - No. 4. - P.559-565.

5. Influence of polyvinylchloride on the chemical and thermal resistance of highly filled polyester composites / Levyts'kyi V.E., Katruk D.S., Kochubei V.V., Humenets'kyi T.V., Bilyi L.M., Masyuk A.S. // Materials Science. - 2017. - Vol.53. - No. 3. P.385-391.

6. Twin screw extrusion with Expancel foaming agent / Sikora J.W., Levytskyi V., Moravsky V., Gerlach H. // Journal of Polymer Engineering. - 2013. - Vol.33. - No. 6. P.501-508.

7. Sidelkovskaya F.P. Khimiya N-vinilpirrolidona i ego polimerov. - Moscow: Nauka, 1970. - 150 p.

8. Levytskyi V.Ye., Masyuk A.S., Suberlyak O.V. Preparation and properties of polymer-silicate composites based on hydrophilic polymers // Voprosy Khimii i Khimicheskoi Tekhnologii. - 2017. - No. 6. - P.68-74.

9. Harper C.A. Handbook of plastic processes. - Hoboken: John Wiley \& Sons, 2006. - 743 p.

10. Dealy J.M., Wissbrun K.F. Melt rheology and its role in plastics processing: theory and applications. - Dordrecht: Kluwer Academic Publishers, 1990. - 680 p.

11. Malkin A.Ya., Chalykh A.E. Diffuziya i v'yazkost' polimerov: metody izmereniya. - Moscow: Khimiya, 1979. - 
$303 \mathrm{p}$.

12. Chang D.H. Reologiya v protsessakh pererabotki polimerov. - Moscow: Khimiya, 1979. - 366 p.

13. Gupta R.K. Polymer and composite rheology. - New York: Marcel Dekker, 2000. - 416 p.

14. Mittal $V$. Functional polymer blends: synthesis, properties, and performance. - Boca Raton: CRC Press, 2012. $342 \mathrm{p}$.

Received 13.09.2018

\section{ВПЛИВ МОДИФІКОВАНОГО УЩІЛЬНЕНОГО ПІНОПОЛІСТИРОЛУ НА РЕОЛОГІЧНІ ВЛАСТИВОСТІ ПОЛІКАПРОАМІДУ І ПОЛІСТИРОЛУ}

В.С. Моравський, В.Е. Левицький, А.С. Масюк, У.В. Хром'як

Встановлено вплив модифікованого полівінілпіролідоном ущільненого пінополістиролу на реологічні властивості полікапроаміду і полістиролу. Модифікований пінополістирол суттево впливає на характер залежностей в'язкості розплаву полікапроаміду від напруження зсуву, що викликано фізичними взаємодіями між компонентами системи, насамперед між функціональними групами полікапроаміду і полівінілпіролідону. Виявлено вплив температури і вмісту модифікованого ущільненого пінополістиролу на індекс течії, константи реологічного рівняння та енергію активації в'язкої течії розплавів полікапроаміду і полістиролу. Індекс течії полікапроаміду в ньютонівської області не залежить від вмісту модифікованого пінополістиролу та температури і близький до 1; на неньютонівській діляниі вплив модифікатора на індекс течї̈ розплаву суттєвіше проявляється за низьких температур. Зі збільшенням вмісту модифікованого пінополістиролу зменшується ефективна в'язкість розплаву полікапроаміду, а значення швидкості зсуву початку розвитку аномалї̈ в язкості зростає. Для сумішей полістиролу з модифікованим пінополістиролом значення індексу течії зростає зі збільшенням вмісту модифікованого пінополістиролу $і$ не залежить від температури, що, очевидно, викликано збільшенням вмісту компонента з меншою молекулярною масою, і внаслідок иього, збільшенням загальної полідисперсності системи.

Ключові слова: полікапроамід, пінополістирол, реологічні властивості, суміші полімерів, полівінілпіролідон.

\section{INFLUENCE OF MODIFIED COMPACTED EXPANDED POLYSTYRENE ON THE RHEOLOGICAL PROPERTIES OF POLYAMIDE 6 AND POLYSTYRENE}

V.S. Moravskyi, V.Ye. Levytskyi, A.S. Masyuk *, U.V. Khromiak Lviv Polytechnic National University, Lviv, Ukraine

\section{* e-mail: masyukas@gmail.com}

The influence of the compacted expanded polystyrene modified by polyvinylpyrrolidone on the rheological properties of polyamide 6 and polystyrene are established in this work. The modified expanded polystyrene significantly affects the dependence of the viscosity of polyamide 6 melt on the shear stress, which is caused by physical interactions between the components of the system, primarily between the functional groups of polyamide 6 and polyvinylpyrrolidone. The effects of the temperature and the content of modified expanded polystyrene on the flow behavior index, the constant of the rheological equation and the activation energy of the viscous flow of polyamide 6 and polystyrene melts are revealed. The polyamide 6 flow behavior index in the Newtonian region is independent of the content of modified expanded polystyrene and temperature and is close to 1 . The influence of the modifier on the flow behavior index in the non-Newtonian region is more pronounced at low temperatures. With an increase in the content of modified expanded polystyrene, the effective viscosity of the polyamide 6 melt decreases, and the value of the shear rate of the beginning of development of the anomaly of viscosity increases. The value of the flow behavior index of the blends of polystyrene with modified expanded polystyrene increases with an increase in the content of modified expanded polystyrene and does not depend on the temperature. This is obviously due to an increase in the content of a component with lower molecular weight and, consequently, an increase in the overall polydispersity of the system.

Keywords: polyamide 6; expanded polystyrene; rheological properties; polymer blends; polyvinylpyrrolidone.

\section{REFERENCES}

1. Mai Yiu-Wing, Yu Zhong-Zhen, Polymer nanocomposites. Woodhead Publishing Limited, Cambridge, 2006. 608 p

2. Deopura B.L., Alagirusamy R., Joshi M., Gupta B., Polyesters and polyamides. Woodhead Publishing Limited, Cambridge, 2008. 632 p.

3. Levytskyj V., Laruk Y., Humenetsky T., Sikora J. The influence of polystyrene modifier and plasticizer nature on the properties of poly(vinyl chloride). Chemistry and Chemical Technology, 2015, vol. 9, pp. 199-203.

4. Levyts'kyi V.E., Katruk D.S., Shybanova A.M., Bilyi L.M., Humenets'kyi T.V. Physicochemical properties of modified polyester-polyvinylchloride compositions. Materials Science, 2017, vol. 52, pp. 559-565.

5. Levyts'kyi V.E., Katruk D.S., Kochubei V.V., Humenets'kyi T.V., Bilyi L.M., Masyuk A.S. Influence of polyvinylchloride on the chemical and thermal resistance of highly filled polyester composites. Materials Science, 2017, vol. 53, pp. 385-391.

6. Sikora J.W., Levytskyi V., Moravsky V., Gerlach H. Twin screw extrusion with Expancel foaming agent. Journal of Polymer Engineering, 2013, vol. 33, pp. 501-508.

7. Sidelkovskaya F.P., Khimiya $N$-vinilpirrolidona $i$ ego polimerov [Chemistry of N-vinylpyrrolidone and its polymers]. Nauka, Moscow, 1970. 150 p. (in Russian).

8. Levytskyi V.Ye., Masyuk A.S., Suberlyak O.V. Preparation and properties of polymer-silicate composites based on hydrophilic polymers. Voprosy Khimii $i$ Khimicheskoi Tekhnologii, 2017, no. 6, pp. 68-74.

9. Harper C.A., Handbook of plastic processes. Hoboken, John Wiley \& Sons, 2006. 743 p.

10. Dealy J.M., Wissbrun K.F., Melt rheology and its role in plastics processing: theory and applications. Kluwer Academic Publishers, Dordrecht, 1990. 680 p.

11. Malkin A.Ya., Chalykh A.E., Diffuziya $i$ v'yazkost' polimerov: metody izmereniya [Diffusion and viscosity of polymers: methods of measurement]. Khimiya, Moscow, 1979. 303 p. (in Russian).

12. Chang D.H., Reologiya $v$ protsessakh pererabotki polimerov [Rheology in the processes of polymer processing]. Khimiya, Moscow, 1979. 366 p. (in Russian).

13. Gupta R.K., Polymer and composite rheology. Marcel Dekker, New York, 2000. 416 p

14. Mittal V., Functional polymer blends: synthesis, properties, and performance. CRC Press, Boca Raton, 2012. 342 p. 